\title{
OVERCOMING THE CORPORATE VEIL CHALLENGE: COULD INVESTMENT LAW INSPIRE THE PROPOSED BUSINESS AND HUMAN RIGHTS TREATY?
}

\author{
Anil Yilmaz Vastardis* and Rachel Chambers**
}

\begin{abstract}
This article proposes a model of treaty-based veil piercing for civil liability claims by victims of human rights harm inflicted by businesses. The primary inspiration for this model comes from investment treaty provisions dealing with corporate investors. Our examination of investment law for this purpose exposes the double standard in the treatment of the corporate veil between these two remedy regimes, and offers a way to address this. The test we propose for lifting the veil in order to allow victims to claim against the parent company in a corporate group is one of 'legal control'. It aims to capture cases where the parent did not necessarily take an active role in the subsidiary's business, but it is still treated as being in control of the subsidiary by virtue of its direct or indirect ownership or ability to appoint management.
\end{abstract}

Keywords: Human rights, access to remedy, business and human rights, civil liability, control, corporate veil, investment treaty.

\section{INTRODUCTION}

Transnational business is frequently conducted through a corporate structure of subsidiary companies located and operating in host States. ${ }^{1}$ More often than not the parent company will use layers of intermediaries to distance itself legally from the host State subsidiary and/or to benefit from a favourable regulatory framework. Where corporate related human rights abuses occur in host States, victims in the first instance would be likely to seek to obtain remedy for these in the host State, against the locally incorporated subsidiary. Where the host State has an ineffective legal system or the local subsidiary is underfunded or defunct, victims of such human rights impacts have sought to attribute blame to the parent company for the actions of its subsidiary and to

* Lecturer, School of Law, University of Essex, ayilma@essex.ac.uk.

**PhD Candidate, School of Law, University of Essex, rechama@essex.ac.uk.

1 'Host State' is used in this article as a reference to the State where the victims have suffered the human rights harm. 
obtain a remedy through the courts of the parent company's home State. ${ }^{2}$ A pressing issue arising from the victims' inability to obtain justice locally ${ }^{3}$ is whether they can pursue the parent company in the home State's courts for the harm inflicted by its subsidiary's activities that materialized in the host State. In order to successfully advance such a claim, claimants need to overcome, inter alia, the 'corporate veil' challenge, a path fraught with difficulties. Obstacles posed by corporate veil in access to remedy have been documented in case law, ${ }^{4}$ scholarly writing ${ }^{5}$ and recognized in the UN Guiding Principles on Business and Human Rights ('UNGPs'). ${ }^{6}$

The UNGPs, in their third pillar on 'access to remedy', reaffirm the duty of States to provide effective remedies to victims of human rights abuses committed by businesses as part of the States' general duty to protect under international human rights law. ${ }^{7}$ In fulfilling this duty States are asked to remove legal and other obstacles, including those created by corporate group structures and denials of justice in host States. ${ }^{8}$ The momentum gained by the endorsement of the UNGPs now continues with a proposal to conclude an internationally binding instrument on business and human rights ('BHR'). ${ }^{9}$ One of the central aims of the UNGPs and the proposed treaty on BHR is to enhance access to effective remedy for victims of corporate related human rights abuses ('BHR claimants'). In this article, we aim to move the discussion forward on what protections a draft convention on business and human rights should contain, and in particular make a concrete proposal on

2 'Home State' is used in this article as a reference to the State where the parent company, whose actions or omissions directly or via its subsidiaries resulted in or contributed to the human rights harm, is located.

3 Other significant barriers to access to justice include costs of litigation, intimidation of victims and witnesses, evidentiary burdens, and limitation periods; See G Skinner et al., 'Third Pillar: Access to Judicial Remedies for Human Rights Violations by Transnational Business' (2013) ICAR CORE ECCJ < http://corporatejustice.org/documents/publications/eccj/the_third_pillar_access_to_judicial_remedies_for_human_rights_violation.-1-2.pdf $>$.

4 Some well-known examples of such cases include, Presbyterian Church of Sudan v Talisman Energy 244 F Supp 2d 289 (SDNY 2003); In re Union Carbide Corp Gas Plant Disaster at Bhopal 634 F Supp 842 (SDNY 1986); Aguinda v Texaco, Inc 142 F Supp 2d 534 (SDNY 2001); Wiwa $v$ Royal Dutch Petroleum 226 F 3d 88 (2d Cir 2000); Recherches Internationales Quebec v Cambior Inc [1998] QJ No 2554, Quebec Super Ct, 14 August 1998; Lubbe v Cape plc [2000] 1 Lloyd's Rep 139 (CA).

5 See for instance S Joseph, Corporations and Transnational Human Rights Litigation (Hart Publishing 2004); G Skinner et al. (n 3) and S Baughen, Human Rights and Corporate Wrongs: Closing the Governance Gap (Edward Elgar 2015) 179-90.

6 UNOHCHR, 'Report of the Special Representative of the Secretary-General on the Issue of Human Rights and Transnational Corporations and Other Business Enterprises, John Ruggie' (2011) UN Doc A/HRC/17/31; UNOHCHR, 'Guiding Principles on Business and Human Rights: Implementing the United Nations "Protect, Respect and Remedy" Framework' (2011) UN Doc HR/PUB/11/04 <www.ohchr.org/Documents/Publications/GuidingPrinciplesBusinessHR_ EN.pdf>; UN Human Rights Council endorsed the Guiding Principles in its resolution 17/4 of 16 June 2011, Guiding Principle 26. $\quad{ }^{7}$ Principle 25, UNGPs. $\quad{ }^{8}$ Principle 26 UNGPs.

${ }^{9}$ UN Human Rights Council Resolution on 'Elaboration of an international legally binding instrument on transnational corporations and other business enterprises with respect to human rights' (2014) UN Doc A/HRC/RES/26/9. 
how it can enhance access to remedy. A treaty in this area promises to make a significant contribution to enhancing access to remedy. We propose that as part of a framework to enhance access to remedy, the treaty should contain a model of treaty-based veil piercing. This model would carve out an exception to the classic rule of separate personality for civil liability claims brought against parent companies by workers and communities whose human rights have been impacted by the activities of the subsidiary.

The essence of our proposal is guided by the treaty-based veil-piercing model found in international investment law ('IIL'), which treats the issue of the corporate veil quite differently from the way in which it is treated in the civil liability claims under consideration. ${ }^{10}$ Despite key parallels in obstacles in access to remedy created by local denials of justice and by the corporate veil in both areas, the existing legal framework contains a double standard which favours international investors when it comes to the application of the corporate veil principle. ${ }^{11}$ The corporate veil is more readily disregarded in IIL decisions in order to protect the parent company's access to benefits under an investment treaty, as compared with the difficulty experienced by BHR claimants in piercing the same corporate veil when seeking to hold parent companies liable for harm caused by their subsidiaries. The reason for this is the availability of IIL rules ${ }^{12}$ which allow a reverse piercing of the corporate veil ${ }^{13}$ using a test of 'legal control', ie the parent can claim directly against the host State for harm suffered by directly or indirectly owned subsidiaries. As the current legal framework stands, there are no rules analogous to the IIL rules on veil-piercing which would allow courts to

\footnotetext{
${ }^{10}$ Of necessity, given that our model is inspired by IIL, it does not address the situation where a transnational business is comprised of a series of companies connected by contractual relationships only, rather than through equity ownership; This therefore excludes victims who have suffered human rights abuses at the hands of such contractual partner businesses from access to remedy from our model eg Jabir et al. v KiK Textilien und Non-Food GmbH (Landgericht Dortmund) (Case concerning damages for death and personal injury resulting from fire at factory of primary supplier to the KiK clothing company); ECCHR Case Report available at <www.ecchr.eu/en/ our_work/business-and-human-rights/working-conditions-in-south-asia/pakistan-kik.html>.

${ }_{11}$ This double standard in application of corporate veil principle to investors and victims is not limited to remedies. For instance corporate veil shields shareholders from liability, preventing B\&HR victims from having access to the funds received by the parent but it does not interfere with the upstream flow of profits from the subsidiary to the parent. Areas of law that aim to safeguard the healthy functioning of markets, eg securities law, competition law and IIL, recognize the necessity to disregard separate personality between the shareholders and the company to protect the free market interests, but policymakers have not embraced the same pragmatism to protect against human rights abuses by corporate actors. See G Skinner, 'Parent Company Accountability: Ensuring Justice for Human Rights Violations' (2015) ICAR, 9-10 $<$ https://static1.squarespace.com/static/583f3fca725e25fcd45aa446/t/591c8ebdbf629a23e7e35da0/ 1495043779017/PCAP+Report+2015.pdf> 8-11.

12 Particularly in bilateral investment treaties and the Convention on the Settlement of Investment Disputes between States and Nationals of Other States (adopted 18 March 1965, entered into force 14 October 1966) 575 UNTS 159 ('ICSID Convention').

${ }_{13}$ This concept was previously used in the context of securities litigation where the company is held legally responsible for the liabilities of its shareholders, See for instance Securities Investor Protection Corp. v Stratton Oakmont, Inc., 234 B.R. 293, 321 (S.D. N.Y. 1999).
} 
disregard separate personality in civil liability claims brought by BHR claimants against transnational businesses. States have long carved out exceptions to the separate personality rule in order to maximize investor protection in investment treaties. We argue that protection of human rights is a goal that warrants an equivalent treaty commitment carving out a similar exception for BHR claimants.

BHR and IIL have hitherto been perceived as having restraining effects on their mutual advancement. ${ }^{14}$ The restraining effect of IIL on BHR is partly due to the problem of asymmetry in IIL that it gives rights to investors but places no or minimal obligations on them vis-à-vis the host States or host communities in which they operate. In response to this, proposals have been advanced to include substantive commitments from States in investment treaties to ensure business respect for human rights, ${ }^{15}$ and one new investment treaty goes as far as including rights for the benefit of third parties adversely affected by investor activity in investment treaties. ${ }^{16}$ There have also been numerous discussions on how to overcome the corporate veil challenge to access to remedy. ${ }^{17} \mathrm{In}$ this article, we are proposing a positive contribution from the existing IIL system to the advancement of BHR. The IIL model of treatybased veil piercing is an efficient model for overcoming the corporate veil obstacle and could guide the development of treaty practice in the field of BHR. Granting BHR claimants the right under an international treaty to pursue parent companies in their home jurisdiction, with home States being responsible for ensuring that their laws would allow claims to be made against the parent entity, would assist in closing the accountability gap in

14 On one hand IIL is perceived as restraining advancement of human rights protection from business activity, See for instance UNGA 'Report of the Special Rapporteur of the Human Rights Council on the Rights of Indigenous Peoples on the Impact of International Investment and Free Trade on the Human Rights of Indigenous Peoples' (7 August 2015) UN Doc A/70/ 301; On the other hand, further regulation of corporate activity in the name of human rights protection was perceived as a threat to promotion of investment; See C Jochnick and N Rabaeus, 'Business and Human Rights Revitalized: A New UN Framework Meets Texaco in the Amazon' (2010) 33 SuffolkTransnatlLRev 413, 416-17; On the substance of the relationship between these two fields and home State responsibility see $\mathrm{R}$ McCorquodale and $\mathrm{P}$ Simons, 'Responsibility beyond Borders: State Responsibility for Extraterritorial Violations by Corporations of International Human Rights Law' (2007) 70 MLR 598, 621-3. (They argue that home State facilitation and promotion of overseas investment for the benefit of its corporate nationals by, inter alia, entering into investment treaties could contribute to the failure of the home State to protect human rights, when those corporations commit violations, by creating the conditions for adherence to lower standards.)

15 Watered down commitments to 'corporate social responsibility' were made in some recent investment treaties; see for instance, art 15(2) of the 2014 Canada-Côte d'Ivoire Foreign Investment Promotion and Protection Agreement (adopted 30 November 2014, entered into force 14 December 2015); So far, the strongest safeguards are found in Section 18 of the Reciprocal Investment Promotion and Protection Agreement between the Government of the Kingdom of Morocco and the Government of the Federal Republic of Nigeria (Morocco-Nigeria BIT) signed on 3 December 2016

16 See art 20 of the Morocco-Nigeria BIT.

17 See Section VI(b) below. 
cases involving harm by transnational businesses, bringing victims one step closer to effective remedies.

This article begins by briefly explaining the corporate veil challenge to access to remedy for BHR claimants in cases involving harm caused by transnational business enterprises. This is followed by a discussion of the treatment of the corporate veil under IIL. Having explained the treatment of the corporate veil in both areas, we move on to an analysis of the commonalities and differences between IIL and BHR claims concerning access to remedy and discuss the reasons for piercing the corporate veil in both areas. Using Chevron's legal saga in Ecuador as a case study, this section exposes the differences in the two systems. Building on that comparison and with a view to improving access to remedy for BHR claimants, we then propose a model for treaty-based veil piercing for BHR claims, inspired by the IIL model. While there is already scholarship arguing that the corporate veil should be pierced in the context of human rights violations, we are advancing a novel means of achieving this.

\section{SEPARATE PERSONALITY AS AN OBSTACLE TO ACCESS TO EFFECTIVE JUDICIAL}

\section{REMEDIES BY BHR CLAIMANTS}

Numerous attempts have been made to hold parent companies liable for human rights abuses committed overseas ostensibly by their subsidiaries. ${ }^{18}$ Claimants pursuing this route have frequently relied on causes of action in tort for personal injury, environmental harm, and emotional suffering. ${ }^{19}$ Victims have attempted to hold parent companies liable, sometimes jointly with their host State subsidiaries, before home State courts due to the lack of sufficient legal protections, including ineffective enforcement, ${ }^{20}$ in the host State and/or due to the subsidiary not having sufficient assets to satisfy a judgment. ${ }^{21}$ Particularly in the former instance, pursuing the parent company before the

18 See (n 4).

19 Lubbe v Cape plc [2000] 1 Lloyd's Rep 139 (CA); Bodo Community v Royal Dutch Shell Plc $\&$ Shell Petroleum Development Company (Nigeria) Ltd Case No HQ11X01280; Akpan v Royal Dutch Shell PLC, Arrondissementsrechtbank Den Haag [District Court of The Hague] (30 January 2013) Case No C/09/337050/HA ZA 09-1580 (ECLI:NL:RBDHA:2013:BY9854); Aguinda $v$ Texaco, Inc 142 F Supp 2d 534 (SDNY 2001).

${ }^{20}$ G Skinner (n 11) 3 uses the concept 'high risk country'; See also C van Dam, 'Tort Law and Human Rights: Brothers in Arms on the Role of Tort Law in the Area of Business and Human Rights' (2011) 2 JETL 221, 228; For example the local law may prohibit the type of claim. An example of such a law is the immunity law passed in Papua New Guinea to give Australian company BHP Billiton immunity from prosecution for environmental damage stemming from the construction of its gold and copper mine in the 1990s, see Sydney Morning Herald, 'PNG Government Takes Control of Ok Tedi Mine' (18 September 2013) <www.smh.com.au/business/ png-government-takes-control-of-ok-tedi-mine-20130918-2tzt4.html >; Another example would be local law limitations on the compensation available eg as a result of a national workers' compensation scheme.

21 The South African subsidiary of British company Cape plc was insolvent meaning that no claims could be brought against it by victims of asbestosis caused by the subsidiary in the case of Lubbe v Cape plc [2000] 1 Lloyd's Rep 139 (CA); van Dam (n 20) 228. 
home State court might be the only effective path to a remedy. Litigating in a parent company's home State is also sometimes seen as advantageous as it may open the door to favourable civil procedural arrangements such as class actions, public interest litigation, wide disclosure rules and sophisticated case funding arrangements, which make mounting this type of litigation feasible. ${ }^{22}$

However, company law principles applicable in such cases render holding the parent company liable extremely difficult. The parent company is in law a distinct entity from the subsidiary. The act of incorporation creates a separate legal personality for the newly incorporated company, dividing it and its shareholder-owners into separate spheres and bestowing limited liability on the shareholders. The corporate veil with its corollary of limited liability, which divides the separate juridical personalities of parent and subsidiary company, is a device intended to protect shareholders so as to encourage risk-taking and innovation through investment in the business. ${ }^{23}$ It is important to bear in mind that the corporate veil operates in two directions. It has the effect of shielding shareholders from the liabilities of the company, but it also prevents shareholders from treating the rights held by the company as their own. It has been pointed out by leading scholars that the concept of limited liability originates from a time when corporations were generally not allowed to hold shares in other corporations, meaning that corporate groups did not exist. ${ }^{24}$ The use of the corporate veil to shield parent companies from liability for the debts of their subsidiaries in such groups 'opens the door to multiple layers of insulation [from liability], a consequence unforeseen when limited liability was [first] adopted'25 and one which is arguably hard to justify, particularly in tort cases where the claimant is an involuntary creditor. ${ }^{26}$

The circumstances in which the corporate veil may be pierced vary from State to State but, as a general rule, it is reserved for exceptional cases. ${ }^{27} \mathrm{~A}$ high threshold is set by domestic company laws to depart from the rule. ${ }^{28}$ Veil

${ }^{22}$ R Meeran, 'Tort Litigation against Multinationals for Violation of Human Rights: An Overview of the Position Outside the United States' (2011) 3(1) City University Hong Kong Law Review 3, 13-19; van Dam (n 20) 228.

23 Joseph (n 5) 131.

24 Joseph (n 5) 131 and PI Blumberg, 'Accountability of Multinational Corporations: The Barriers Presented by Concepts of the Corporate Juridical Entity' (2001) 24 HastingsIntl\&CompLRev. 297, 300-4.

25 P. Blumberg, The Multinational Challenge to Corporate Law: The Search for a New Corporate Personality (OUP 1993) 139.

26 P Muchlinski, 'The Changing Face of Transnational Business Governance: Private Corporate Law Liability and Accountability of Transnational Groups in a Post-Financial Crisis World' (2011) 18(2) Ind. J. Global Legal Stud. 665, 669-679 (Involuntary creditors are those that have been caused injury by the company without having entered into a bargain with the company over the allocation of risks).

27 J Zerk, 'Corporate liability for gross human rights abuses: Towards a fairer and more effective system of domestic law remedies' A report prepared for the Office of the UN High Commissioner for Human Rights, 66, <www.ohchr.org/Documents/Issues/Business/DomesticLawRemedies/ StudyDomesticeLawRemedies.pdf $>$

${ }_{28}$ See for an overview of various jurisdictions K Vandekerckhove, Piercing the Corporate Veil (Kluwer Law International 2007). 
piercing may be considered where there has been fraud or where the level of control by the parent company is so extreme as to render the corporation an alter ego or a sham. ${ }^{29}$ As Michael Osborne explains, piercing the veil between an overseas subsidiary and its domestic parent company is made difficult by corporate law rules, and this 'fiction of corporate personality facilitates elaborate shell games, permitting responsibility to be deferred, displaced and diffused across globe-spanning commercial empires.' ${ }^{30}$ It is possible to hold the parent company liable for its subsidiary's actions without piercing the corporate veil by alleging, for example, that the parent company was directly involved in the violation ostensibly committed by its subsidiary. ${ }^{31}$ Attempts have been made to hold the parent directly liable in the home State for human rights harm caused by its subsidiary's business on the grounds that the parent owed a direct duty of care to the victims. ${ }^{32}$ To our knowledge, so far there has not been a judicial determination holding a parent directly liable for overseas harm although there is English precedent for holding the parent directly liable in negligence for physical harm to an employee of its domestic subsidiary. ${ }^{33}$ The only judgment, to our knowledge, that pierced the veil to hold the parent liable for the human rights harm caused by the subsidiary was rendered by courts in Ecuador in a case brought against Chevron, discussed below. ${ }^{34}$

There are typically three stages at which the corporate veil may interfere with access to a judicial remedy for BHR claimants. The first is the jurisdictional stage. While the home State court might have personal jurisdiction over a parent company based on domicile, in order for it to assume subject-matter jurisdiction a claimant bringing a civil claim against a parent company will first have to show that there is sufficient link between the forum and the claim. This generally requires establishing a prima facie case against the parent for a violation committed by its subsidiary. ${ }^{35}$ Formally, since the subsidiary and the parent company are separate legal persons, the latter may be able to benefit from a corporate veil defence. In common law countries,

${ }^{29}$ S Joseph, (n.5) 130.

30 M Osborne, 'Apartheid and the Alien Torts Act: Global Justice Meets Sovereign Equality' in $\mathrm{M}$ du Plessis and S Pete (eds), Repairing the Past? International Perspectives on Reparations for Gross Human Rights Abuses (Intersentia 2007), 241.

31 See R Chambers and K Tyler, 'The UK Context for Business and Human Rights' in L Blecher et al. (eds), Corporate Responsibility for Human Rights Impacts: New Expectations and Paradigms (American Bar Association 2014) 304 and R Meeran, (n. 22) 5.

32 For an overview of some of the attempts in England, see R Meeran (n 22).

33 See Chandler $v$ Cape for a precedent holding the parent directly liable in negligence for physical harm to the employee of its domestic subsidiary.

34 This case is explored below in Section V; Maria Aguinda et al. v Chevron Corporation Lawsuit No. 2003-0002, Sucumbíos Provincial Court of Justice, judgment text available at $<$ https://www.earthrights.org/sites/default/files/documents/Lago-Agrio-judgment_0.pdf >; For a finding on the contrary, see Adams v Cape Industries Plc [1991] 1 All ER 929.

${ }^{35} \mathrm{C}$ van Dam (n 20) 230 ('In order for the European forum to have jurisdiction a link is required between the forum and the claim. To establish this link the court may need to consider the merits of the claim at an early stage.') 
even where the court has jurisdiction over the case, it may nonetheless be struck out under the forum non conveniens rule if the court decides that there is a more appropriate forum elsewhere. ${ }^{36}$ The decision on whether there is a more appropriate forum might be influenced by the fact that the defendant parent company and its overseas subsidiary are separate entities. In European Union jurisdictions, Brussels Regulation (Recast) ${ }^{37}$ eliminates the availability of the forum non conveniens defence by allowing the parent company to be sued in the country where it is domiciled, without having to show that the home State is the most appropriate forum in which to hear the case. Nevertheless, the requirement to show a prima facie case against the parent remains, and might prevent home State courts from exercising jurisdiction over claims concerning subsidiary business. ${ }^{38}$

The second stage, assuming the jurisdictional hurdle is overcome, is the merits stage where the court decides whether to disregard the corporate veil and to attribute liability to the parent company for harm caused by the subsidiary's activities. The outcome of this is rarely positive for BHR claimants. ${ }^{39}$ They have to tackle the almost impossible task of demonstrating that the parent created the subsidiary for fraudulent purposes, or that the subsidiary was the alter ego or agent of the parent. In direct parent liability cases claimants must prove that the parent owed a direct duty of care to them, ${ }^{40}$ and thus it was not the subsidiary's breach alone that caused the harm, but also the parent's breach of its own duty. ${ }^{41}$ This is difficult for

36 In Recherches Internationales Quebec v Cambior Inc., unreported judgment of 14 August 1998 (Canada Superior Court, Quebec, no. 500-06-000034-971) the court dismissed proceedings brought by a public interest group against a Canadian mining company following the spill of cyanide contaminated tailings at a subsidiary mine's site, on grounds of forum non conveniens. Meeran, (n. 22) 11; Joseph (n 5) 88.

37 Regulation (EU) No 1215/2012 of the European Parliament and of the Council of 12 December 2012 on jurisdiction and the recognition and enforcement of judgments in civil and commercial matters (recast), published on the Official Journal of the European Union on 20.12.2012; Case C-281/02 Andrew Owusu v N.B. Jackson [2005] ECR I-1383.

38 See His Royal Highness Emere Godwin Bebe Okpabi and Others v Royal Dutch Shell Plc 2017 EWHC 89 (TCC) para 69.

39 Two patterns can be observed post-jurisdiction stage: (1) cases get settled out of court without admission of liability, see Lubbe v Cape Plc [2000] 1 WLR 1545 (HL) and Bodo Community v Royal Dutch Shell Plc \& Shell Petroleum Development Company (Nigeria) Ltd Case No HQ11X01280 and Wiwa v Royal Dutch Petroleum 226 F 3d 88 (2d Cir 2000); (2) parent company is not held liable on the merits, see Akpan v Royal Dutch Shell PLC, Arrondissementsrechtbank Den Haag [District Court of The Hague] (30 January 2013) Case No C/09/337050/HA ZA 09-1580 (ECLI: NL:RBDHA:2013:BY9854).

${ }^{40}$ For example Akpan ibid. See also Chandler v Cape plc [2012] EWCA Civ 525, CSR Ltd v Wren (1997) 44 NSWLR 463 (CA NSW).

41 In these instances, there seems to be a rebuttable presumption that the subsidiary is in charge of its own policies/activities, since it has separate personality from its shareholders/parent. In these circumstances, the parent does not owe a duty of care to the victims. But this presumption can be rebutted if the claimants can show, inter alia, that the parent company itself has disregarded the corporate veil and has taken charge of/controlled certain policies/activities of the subsidiary, thus assuming a direct duty of care towards the victims. Rebuttal of this presumption allows for the court to hold the parent directly liable under the relevant civil liability principles. The threshold 
claimants to do: the strictures of the corporate veil loom despite the fact that through the formulation of their legal claim, claimants do not actually seek to pierce it. $^{42}$

The third stage is the enforcement stage where the corporate veil might be an obstacle to a remedy. BHR claimants might obtain a favourable judgment for damages in the host State against the subsidiary, but nevertheless be unable to enforce the judgment due to the subsidiary being impecunious or defunct. They might wish to enforce such a judgment against the parent, but they are likely to be unsuccessful as the corporate veil principle would prevent them from holding the parent liable for the debts of the subsidiary.

\section{IIL AND TREATY-BASED VEIL PIERCING: HOW DOES IT OPERATE?}

IIL deals with the substantive ${ }^{43}$ and procedural rights of foreign investors $v i s-a$ vis host States. Its primary sources include a web of bilateral, regional and sectoral investment treaties, the ICSID Convention and customary international law. The procedural empowerment of investors by the IIL instruments strengthens their access to remedies thus enabling the effective enforcement of substantive IIL protections. ${ }^{44}$ But an entity must qualify as a foreign investor in order to benefit from IIL protections. Investors who desire the backing of 'international law' for their investments typically structure the corporate relationships involved in their investment in a way that will secure the protection of a strong investment treaty. 45

The ICSID Convention and investment treaties contain personal and material scope rules that allow direct or indirect shareholders or controllers of a host State subsidiary to bring claims against the host State for the harm caused by the latter to the subsidiary's business. These treaty provisions allow investment tribunals,

for rebutting this presumption by showing that the necessary level of involvement exists is a high one.

42 This was successfully done in Chandler $v$ Cape plc. Arden LJ explicitly noted that the case was not about veil-piercing, para 69; however, it is possible to argue that in effect the decision disregarded the separation between the parent and the subsidiary where certain conditions were met; the claimants in Akpan (n 39) were unable to convince the court to find a direct duty of care on the parent, as the latter was a separate entity and did not satisfy the conditions set by the court in the Chandler judgment.

${ }^{43}$ Substantive rights guaranteed typically include national treatment and most favoured nation treatment clauses, right to compensation for expropriation of investment, right to a fair and equitable treatment, the right to receive full protection and security and free transfer of funds.

${ }^{44}$ Procedural rights contained in investment treaties typically include a right to settle disputes with the host State before an international arbitration tribunal.

${ }^{45}$ See R van Os and R Knottnerus, Dutch Bilateral Investment Treaties: A Gateway to 'Treaty Shopping' for Investment Protection by Multinational Companies (October 2011) SOMO 9 (defines treaty shopping as "the conduct of foreign investors in acquiring the benefits of investment treaties in their actual or planned host State through third countries, through which their investment needs to be routed'); E Zuleta et al., 'Treaty Planning: Current Trends in International Investment Disputes That Impact Foreign Investment Decisions and Treaty Drafting' in MA Fernandez-Ballesteros and D Arias (eds), Liber Amicorum Bernardo Cremades (La Ley 2010). 
for the purposes of determining their jurisdiction and the personal scope of application of an investment treaty, ${ }^{46}$ to disregard the separate personality between the host State entity and its shareholders without having to justify this under the limited domestic law grounds for lifting the corporate veil. This is what we call a 'treaty-based reverse veil piercing'. Treaty provisions allow the veil or veils of a number of entities to be disregarded to enable the direct or indirect shareholders or controllers to advance a claim which would, under the company law rules on separate personality, have belonged to the local subsidiary.

\section{A. The ICSID Convention}

The ICSID Convention ${ }^{47}$ uses 'nationality' as the criterion for determining the personal scope of jurisdiction. To benefit from the dispute settlement framework created by the Convention, a corporate investor must be a foreign national. For corporate investors, which make up the vast majority of IIL claimants, the Convention envisages two scenarios for determination of foreign nationality: (1) corporate investors that invest without a separately incorporated local subsidiary are treated as 'foreign', and (2) corporate investors that operate in the host State via a local subsidiary are prima facie treated as domestic, but can be treated as foreign if the local subsidiary is 'controlled' by a foreign entity. ${ }^{48}$ The latter type is the more common method of foreign investment, and it is the treatment of this type of investment that falls within the scope of this article.

Though Article 25(2)(b) stipulates the application of a 'control' test to determine the nationality of the host State entity, it does not clarify what is meant by 'control'. The meaning of 'control' has been interpreted in various arbitral awards. ${ }^{49}$ The significance of this part of Article 25(2)(b) is that it

\footnotetext{
46 The merits of the claim, and what States can be held liable for under the applicable investment treaty, contract, or legislation is a separate question and will be determined with reference to the substantive provisions of the applicable instrument.

47 The ICSID Convention concerns only the procedural rights of investors. It sets up a legal framework for the settlement of investment disputes between investors and host States, using international arbitration as the primary method of dispute resolution. Conciliation is also provided in the Convention, but not used often.

48 Art 25(2) "National of another Contracting State" means: (b) any juridical person which had the nationality of a Contracting State other than the State party to the dispute on the date on which the parties consented to submit such dispute to conciliation or arbitration and any juridical person which had the nationality of the Contracting State party to the dispute on that date and which, because of foreign control, the parties have agreed should be treated as a national of another Contracting State for the purposes of this Convention.' Consent (which may be inferred) is the other requirement under this Article for a local corporation to be treated as possessing the nationality of the relevant contracting State.

${ }^{49}$ See for instance, Quiborax S.A., Non Metallic Minerals S.A. and Allan Fosk Kaplún v Plurinational State of Bolivia, (Decision on Jurisdiction) (ICSID Arbitral Tribunal Case No ARB/06/2 (27 September 2012) para 195; AES Summit Generation Limited and AES-Tisza Erömü Kft v The Republic of Hungary (Award) (ICSID Arbitral Tribunal Case No ARB/07/22
} 
looks behind the corporate veil of the host State subsidiary, for the purpose of determining the foreign nationality of the investor, without having to justify this under the limited domestic company law grounds for lifting the corporate veil.

\section{B. Investment Treaties}

An investor falling under the personal scope of an investment treaty, provided temporal and material requirements are also satisfied, will be able to benefit from the substantive protections of the treaty and enforce these under the dispute settlement provisions of the treaty. ${ }^{50}$ For corporate investors, an overwhelming majority of treaties refer, as the determinant of personal scope, to criteria such as place of incorporation, seat or centre of management. ${ }^{51}$ Occasionally, bilateral investment treaties ('BITs') refer directly to the 'nationality' of corporate investors in order to determine personal scope, but nationality is determined by reference to criteria such as place of incorporation, seat or centre of management. ${ }^{52}$

If the investment in the host State is carried out through a local subsidiary, reverse veil piercing allows the shareholder/parent company established in the home State to claim in the place of its subsidiary. Most investment treaties allow the direct or indirect controllers to benefit from the treaty's protections, so long as the controllers fall within the personal scope of the treaty, ie they are nationals/companies of the home contracting State. In this way a parent company is able to bring a treaty claim against the host State for the harm suffered by its subsidiary. Many investment treaties also include within their material scope direct or indirect ownership of shares as 'investment', which makes it possible for minority shareholders to advance

(23 September 2010) paras 6.1.4-6.1.6; Millicom International Operations BV and Sentel GSM SA (Sentel) v The Republic of Senegal (Senegal) (Decision on Jurisdiction of the Arbitral Tribunal) (ICSID Arbitral Tribunal Case No ARB/08/20 (16 July 2010) para 109; Fraport AG Frankfurt Airport Services Worldwide v Republic of the Philippines (Award) (ICSID Arbitral Tribunal Case No ARB/03/25 (16 August 2007); Tidewater Inc, Tidewater Investment SRL, Tidewater Caribe, CA, Twenty Grand Offshore, LLC, Point Marine, LLC, Twenty Grand Marine Service, LLC, Jackson Marine, LLC, Zapata Gulf Marine Operators, LLC (Tidewater) v The Bolivarian Republic of Venezuela (Venezuela) (Decision on Jurisdiction) (ICSID Arbitral Tribunal, Case No ARB/10/5 (8 February 2013).

${ }^{50}$ If the treaty provides for it, the investment treaty claim might be brought under the ICSID Convention or under another arbitral procedure. As such, the investment treaty constitutes the consent of the disputing parties to ICSID arbitration. The host State making a standing offer to arbitrate to home State investors by entering into the treaty. This standing offer can be accepted by the home State investor by initiating the arbitral proceedings.

51 See for instance, Article 1 of the Agreement Between Canada and the Republic of Serbia for the Promotion and Protection of Investments (adopted 1 September 2014, entered into force 27 April $2015)<$ http://investmentpolicyhub.unctad.org/IIA/country/35/treaty/3502>; For a detailed analysis of investment treaty trends see, Scope and Definition: A Sequel, UNCTAD Series on Issues in International Investment Agreements II (28 February 2011) UNCTAD/DIAE/IA/2010/2, 80-84.

52 See for instance, Article 1(b) of the Agreement on promotion and protection of investments between the Government of the Kingdom of the Netherlands and the Government of the Kingdom of Bahrain (adopted 5 February 2007, entered into force 1 December 2009) 2649 UNTS 13. 
claims for the harm they suffered as the subsidiary's shareholders, de facto disregarding separate personality. ${ }^{53}$ This way, what might otherwise be characterized as a domestic dispute between the subsidiary and the host State is transformed into an international investment dispute that attracts the protection of an investment treaty.

For instance, in the US-Ecuador BIT ${ }^{54}$ reverse veil piercing is made possible by a number of provisions of the treaty. A 'company' that has an 'investment' in Ecuador is able to benefit from the investment treaty protections, including the right to bring arbitration proceedings against the host State. ${ }^{55}$ Pursuant to Article 1(a), 'investment' includes investments 'owned or controlled directly or indirectly by nationals or companies of the [home state]'. The investment itself could take the form of 'a company or shares of stock or other interests in a company or interests in the assets thereof'. This covers investments that are owned directly or indirectly by the protected investor and take the form of a company, ie a subsidiary, established in the host State.

Article 1(b) defines 'company' as one which is 'legally constituted under the laws and regulations of a Party'. The commentary attached to the treaty explains that the word 'company' should be interpreted flexibly so as to afford protection 'even if the parent company is ultimately owned by non-Party nationals' ${ }^{56}$ or even where the investment is made by 'a company of a third country that is owned or controlled by nationals or companies of a Party'. The flexible interpretation envisaged in the commentary allows a corporate group to utilize the existence of the parent or a subsidiary in a particular jurisdiction for the benefit of the whole group, no matter which particular entity is carrying out the investment in the host State or no matter which particular entity directly holds shares in that subsidiary, so long as that entity is within the upstream ownership structure of the host State subsidiary. In this way, corporate veils can be disregarded throughout the various layers of the group structure.

\section{C. 'Control' under IIL}

The ICSID Convention does not provide guidance on the meaning of 'control'. Some investment treaties, like the US-Ecuador BIT, refer to 'direct or indirect'

\footnotetext{
53 See for instance, Enron Corporation and Ponderosa Assets, L.P. v Argentine Republic (Decision on Jurisdiction) ICSID Arbitral Tribunal Case No ARB01/3 (14 January 2004) (the investor held 35.263 per cent interest in the local business); CMS Gas Transmission Company v The Republic of Argentina (Decision of the Tribunal on Objections to Jurisdiction) (ICSID Arbitral Tribunal Case No ARB/01/8 (17 July 2003) (the investor held 29.42 per cent in the local business).

${ }^{54}$ Treaty between the United States of America and the Republic of Ecuador concerning the Encouragement and Reciprocal Protection of Investment (adopted 27 August 1993, entered into force 11 May 1997).

55 ibid, art 6 .

56 'although the other Party may deny the benefits of the Treaty in the limited circumstances' provided in art 1(2).
} 
control and ownership as descriptors, but this is very limited guidance. Other investment treaties, ${ }^{57}$ like the Hong Kong-Australia BIT, go one step further and define control by reference to holding a 'substantial interest' in the subsidiary. ${ }^{58}$ In the absence of clear guidance from treaties, one might turn to the arbitral awards applying and interpreting them for answers. Tribunals tackle two main issues when deciding who the investor behind the host State entity is. The first concerns the indicators of control. So far, ownership/shareholding, voting rights, management rights ${ }^{59}$ and capital investment ${ }^{60}$ in the host State entity have been considered when determining the identity of the controller. Tribunals most frequently consider share ownership as an indicator of control. ${ }^{61}$ The second issue concerns when shareholding is taken as an indicator of control and the host State entity's upstream ownership structure is formed of multiple layers. In such cases, the question arises as to which entity or person exercises 'control' over the host State entity within the meaning of the applicable treaty. Is 'control' exercised by the immediate shareholders ${ }^{62}$ of the host State entity or is there a need to look beyond the immediate shareholders in the upstream structure to identify the controllers? In the latter case, is it necessary to identify the entity exercising actual day to day control? Or, could the tribunal attribute control to an entity within the upstream ownership of the host State company that legally has the ability to exercise control, regardless of the level of its involvement in the subsidiary's business operations?

A common feature observed from arbitral awards is that IIL tribunals do not search for day-to-day control of the subsidiary, in order to attribute the 'protected investor' status to a direct or an indirect shareholder under the applicable treaty. There is, however, a diversity of approaches in what level of involvement is required short of day-to-day control. In some cases,

\footnotetext{
57 Some investment treaties provide limitations to the meaning of control by way of denial of benefits clauses. See for instance, art 17 of the Energy Charter Treaty (adopted 17 December 1994, entered into force 16 April 1998) 2080 UNTS 95; some treaties contain a vague definition like art 1 (d) of the Agreement on Reciprocal Encouragement and Protection of Investments between the Kingdom of the Netherlands and the Republic of Turkey (adopted 27 March 1986, entered into force 1 November 1989); Others remain silent like the Agreement between the Swiss Confederation and Georgia on the Promotion and Reciprocal Protection of Investments (adopted 3 June 2014, entered into force 17 April 2015).

${ }_{58}$ Art 1(e) of the Agreement between the Government of Hong Kong and the Government of Australia for the Promotion and Protection of Investments; the meaning of 'substantial interest' is not provided in the treaty.

59 Liberian Eastern Timber Corporation (LETCO) v Republic of Liberia (Award) (ICSID Arbitral Tribunal Case No ARB/83/2 (31 March 1986) French translation of English original in 115 Journal du droit international 167 (1988) (excerpts).

${ }^{60}$ Dissenting opinion of Prosper Weil in Tokios Tokelés v Ukraine (Decision on Jurisdiction) (ICSID Arbitral Tribunal Case No ARB/02/18 (29 April 2004).

61 See Quiborax S.A., Non Metallic Minerals S.A. and Allan Fosk Kaplún v Plurinational State of Bolivia (Decision on Jurisdiction) (ICSID Arbitral Tribunal Case No ARB/06/2 (27 September 2012) para. 195.

${ }^{62}$ See Amco Asia Corporation and others v Republic of Indonesia (Decision on Jurisdiction) (ICSID Arbitral Tribunal Case No ARB/81/1 (25 September 1983) 23 ILM 351 (1984).
} 
tribunals have sought to identify whether the shareholder that claims to be the investor is a genuine entity that has the ability to exercise control over the subsidiary, and not a shell holding company. ${ }^{63}$ Other tribunals have considered the 'potential' to exercise control via ownership/shareholding sufficient, ${ }^{64}$ even where the entity invoking the investor status is a shell holding company established in a jurisdiction with a favourable investment treaty with the host State. ${ }^{65}$ These latter claims are brought by a shell holding company as the 'controlling entity', which is in turn owned directly or indirectly by a parent company established in a country that has not signed an investment treaty with the host State. Since these shell entities are mere vehicles with no actual activities, their ability to exercise 'control' is doubtful. This so-called practice of treaty shopping via shell companies has led some scholars to argue that tribunals should look beyond formalistic appearances and pay due regard to economic realities when assessing control under IIL in order to prevent exploitation of the protection mechanism, an approach that we agree with. ${ }^{66}$ The awards that support this approach also do not hesitate to look beyond the corporate veils of any entity in the upstream ownership structure of the host State subsidiary to identify the entity which is genuinely able to exercise legal control over the investment. ${ }^{67}$

${ }^{63}$ Banro American Resources, Inc. and Société Aurifère du Kivu et du Maniema S.A.R.L. (Banro American) v Democratic Republic of the Congo (DRC) (Award) (ICSID Arbitral Tribunal Case No ARB/98/7 (1 September 2000) excerpts of the award published on 17 ICSID Rev. - FILJ 382 (2002); TSA Spectrum de Argentina S.A. v Argentine Republic (Award) (ICSID Arbitral Tribunal Case No ARB/05/5 (19 December 2008); Standard Chartered Bank v United Republic of Tanzania (Award) (ICSID Arbitral Tribunal Case No ARB/10/12 (2 November 2012) para 200; Burimi SRL and Eagle Games SH.A v Republic of Albania (Award) (ICSID Arbitral Tribunal Case No ARB/11/18 (29 May 2013) paras 115-121.

${ }^{64}$ See Autopista Concesionada de Venezuela C A v Bolivarian Republic of Venezuela (Decision on Jurisdiction) (ICSID Arbitral Tribunal Case No ARB/00/5 (27 September 2001) (the potential to control was found sufficient).

65 See Mobil Corporation, Venezuela Holdings, B.V., Mobil Cerro Negro Holding, Ltd., Mobil Venezolana de Petróleos Holdings, Inc., Mobil Cerro Negro, Ltd., and Mobil Venezolana de Petróleos, Inc. v Bolivarian Republic of Venezuela (Decision on Jurisdiction) (ICSID Arbitral Tribunal Case No ARB/07/27 (10 June 2010).

${ }^{66} \mathrm{CH}$ Schreuer et al., The ICSID Convention: A Commentary (2nd edn, Cambridge University Press 2009) 323; M Sornarajah, The International Law on Foreign Investment (3rd edn, Cambridge University Press 2010) 327-8.

67 Banro American $v$ DRC (Award) para 7 (the tribunal stressed that control would not be decided on formal appearances, but it also did not seek a high level of involvement by the parent in the subsidiary's business in order to determine who the 'investor' is. The tribunal chose to look behind the veil of the various subsidiaries holding shares in the local subsidiary 'to reveal the parent company as the actual Claimant' thereby 'allowing the financial reality to prevail over legal structures'.). In SOABI v Senegal the tribunal held that the Convention was not solely concerned with the direct control of the local entity by its immediate shareholders. It was natural that investors may choose to channel their investments 'through intermediary entities while retaining the same degree of control over the national company as they would have exercised as direct shareholders of the latter'. See Société Ouest Africaine des Bétons Industriels (SOABI) v State of Senegal (Decision on Jurisdiction) (ICSID Arbitral Tribunal Case No ARB/82/1 (1 August 1984) 2 ICSID Reps 165 (1994) paras 35-37. 
It is difficult to make generalizations as to the meaning of control under IIL due to the diversity of the applicable legal instruments and the diversity in the approaches of arbitral tribunals. In our proposal, we borrow the one common feature of control present in all the awards we have reviewed: when international investment arbitration ('IIA') tribunals determine the personal scope of their jurisdiction through a search for the controllers, they deviate from the tight level of control required by the traditional rules on piercing the corporate veil. The IIL model does not look for a heightened involvement of the controllers in the subsidiary's business. At most, IIL requires the controllers to be a genuine entity, and not a shell holding company, acting as the economic force behind the local subsidiary with an ability to provide a general direction to the subsidiary's business. The permissive language used in BITs and interpretations adopted by IIA tribunals demonstrate that the threshold of control required by IIL to trigger treaty-based veil piercing is significantly lower than that which is typically required by domestic law as grounds for piercing the veil in BHR claims. It is the model of treaty-based veil piercing and this permissive approach to control under IIL that we aim to borrow from the IIL remedial regime for a treaty-based veil piercing in BHR claims involving transnational businesses. Building on this permissive treaty-based approach, for purposes of increasing legal certainty, our model contains a clear definition of control.

\section{COMPARING THE POSITION OF FOREIGN INVESTORS WITH BHR CLAIMANTS}

The corporate veil can pose an obstacle to access to remedy for both BHR claimants and foreign investors. We argue that an exception to the separate personality rule should be carved out for BHR claimants under international human rights law ('IHRL'), similar to the exception carved out for the protection of investors under IIL. It is useful to draw appropriate analogies from more established areas of law in order to develop solutions to particular challenges in newly emerging areas of law. ${ }^{68}$ Although IIL itself is an emerging area of law, BHR is an even younger field which can benefit from being analogized to the more established principles of the IIL regime. They share a sufficient number of relevant characteristics ${ }^{69}$ that

${ }^{68}$ This is explained by A Roberts in her work on analogies drawn to develop IIL. She states that '[w] hen a field is young, it is common for many issues to remain unresolved, leading participants to draw analogies with more established legal disciplines in seeking to provide content and form to the new field'. A Roberts, 'Clash of Paradigms: Actors and Analogies Shaping the Investment Treaty System' (2013) 107 AJIL 45, 50.

69 IHRL and IIL both aim to protect fundamental rights of private parties against State abuse, require States to provide protection against unjustified third-party interference with rights, and enhance access to justice when such abuses are committed by States and by third parties. Both areas enjoin States from invoking their national law to justify violations of their respective rules; and both areas have treaty frameworks that allow private parties to bring a treaty claim against the State directly; see Roberts (n 68) 69-75; PM Dupuy and JE Vinuales, 'Human Rights and 
allow us to draw certain analogies between the treatments of corporate veil in these fields. ${ }^{70}$

Most generally, IIL protections have been developed with the underlying assumption that foreign investors are in a position of vulnerability vis-à-vis host States and, therefore, they need substantive and procedural rights guaranteed under international law. ${ }^{71}$ BHR claimants are arguably in an even more vulnerable position in relation to transnational businesses in defending their basic rights and they strongly deserve substantive and procedural support of international law. States often include procedural guarantees in their investment treaties to enhance access to remedies for investors. Under the IHRL framework, States have a duty to protect against abuses by third parties, including business enterprises. As part of this duty, they are required to establish effective remedy mechanisms when third party abuses occur. IIL and BHR both have a strong emphasis on access to remedy to safeguard the basic rights of their respective beneficiaries.

Besides the relative disadvantaged position of these two sets of defendants, having the fragmented transnational business enterprise as a key actor in both domains necessitates veil piercing in order to enhance access to remedies for their beneficiaries. IIL has effectively dealt with this issue by introducing treaty-based veil piercing, which we argue below is a constructive example to follow in dealing with the same challenge in the BHR context. Given that lack of access to remedies for individual victims is a problem in the IHRL context, ${ }^{72} \mathrm{a}$ similar approach to IIL can be taken by States to assist in fulfilling their duty to provide access to effective remedies to BHR claimants harmed by transnational business activity.

IIL grants unique treaty-based rights to foreign investors and treaty-based veil piercing contributes to the effective enforcement of these rights. Internationally guaranteed substantive and procedural rights ${ }^{73}$ are viewed as safeguards against host States that have the power to detrimentally alter the substantive legal framework applicable to an investment or fail to afford

Investment Disciplines: Integration in Progress' in M Bungenberg et al. (eds), International Investment Law (Nomos 2015) 15.

${ }_{70}$ There are some fundamental differences between these two areas, the primary one being the identity of the defendants, but we do not view these as relevant to the treatment of corporate veil; CR Sunstein, 'On Analogical Reasoning' (1993) 106 HarvLRev 741, 745. ('For analogical reasoning to operate properly, we have to know that $A$ and $B$ are "relevantly" similar, and that there are not "relevant" differences between them ... The major challenge facing analogical reasoners is to decide when differences are relevant.')

${ }^{71}$ C Schreuer, 'Do We Need Investment Arbitration?' in JE Kalicki and A Joubin-Bret (eds), Reshaping the Investor-State Dispute Settlement System: Journeys for the 21st Century (Brill Nijhoff 2015).

72 D Shelton, Remedies in International Human Rights Law (Oxford University Press 2006) 1-4.

${ }^{73}$ See for instance, M Waibel, 'Investment Arbitration: Jurisdiction and Admissibility' (2014) University of Cambridge Faculty of Law Research Paper No 9/2014 at $5<$ http://papers.ssrn.com/ sol3/papers.cfm?abstract_id=2391789> ('access to impartial fora is seen as essential to the realisation of the substantive legal obligations that States have undertaken'). 
effective judicial protection to investors. Treaty-based veil piercing is an important pillar of the procedural empowerment of foreign investors, allowing them to present claims before arbitral tribunals which would have, under the principle of separate personality, belonged to their subsidiaries and been litigated in host State courts. ${ }^{74}$ The IIL rules on treaty-based veil piercing maximize the number of foreign investors that can benefit from IIL protections.

In the BHR context, claimants are in a similarly disadvantageous position in relation to transnational corporations, both substantively and procedurally. The lack of binding IHRL obligations for businesses, weak legal standards and weak enforcement in host States necessitate unique rights for BHR claimants, to be codified in an international treaty accompanied with treaty-based veil piercing, in the same way that foreign investors have unique rights against host States. Procedurally, there is a similar lack of confidence in the ability of victims to obtain effective remedies locally, ${ }^{75}$ and save for exceptional circumstances, BHR claimants are unable to reach the pockets of the parent company due to the latter being a separate person from its local subsidiary. Both types of dispute usually involve a local subsidiary carrying out business in the host State and a parent company based in the home State holding the shares of the local subsidiary, sometimes indirectly through a complex upstream corporate structure. In both cases, the local subsidiary is usually directly linked to the violation, but the parent company might not be. In investment cases, it would be the local subsidiary's property that has been expropriated or licence that has been cancelled. In BHR claims, it is the local subsidiary's activities that ostensibly cause the harm suffered by the victims. In both fields, the question arises as to whether the parent company should be a party to the dispute in lieu of or in addition to its subsidiary in a transnational context, and thus benefit from or suffer the consequences of the judgment or award made. When considering these similarities in corporate structures involved, we should bear in mind that it is often the same transnational businesses that benefit from IIL protections that act as defendants in the type of BHR claims addressed here. ${ }^{76}$

\footnotetext{
74 Availability of investment arbitration and the financial ability of the investors to pursue IIL claims are the other important factors.

75 UNGPs Principle 26's commentary lists among the legal barriers to access to remedy potential denial of justice in a host State and inability to access home State courts; P Simons and A Macklin, The Governance Gap: Extractive Industries, Human Rights, and the Home State Advantage (Routledge 2014) 6 (state that 'a large proportion of corporate human rights violations take place in developing States', where access to remedies might be challenging); see also D Shelton, 'Normative Evolution in Corporate Liability for Violations of Human Rights and Humanitarian Law' (2010) 15 ARIEL 45, 54-5.

${ }^{76}$ H Ward, 'Governing Multinationals: The Role of Foreign Direct Liability' (2001) Royal Institute of International Affairs Briefing Paper New Series No 18 <www.iatp.org/files/ Governing_Multinationals_The_Role_of_Foreign_D.pdf $>1$ (Ward describes 'foreign direct liability' claims for human rights harm as the 'flip side of foreign direct investment'.).
} 
The similarities in the corporate structures and relationships involved in the BHR and IIL claims make the IIL approach to veil piercing a suitable model for BHR claims. A main difference between IIL and BHR in this respect is that in IIL veil piercing allows the parent to benefit from the award, while in BHR it would make the parent suffer the consequences of the judgment. At this point, it is important to remember that corporate veil operates in two directions. It has the effect of shielding shareholders from the liabilities of the company, but it also prevents shareholders from treating the rights held by the company as their own. IIL introduces an exception to this general rule by allowing shareholders to advance claims against host States for abuses suffered by the local subsidiary, a right that is normally reserved for the local subsidiary. The same economic realities and structures of transnational business affect access to remedy in both domains. In both instances, the availability of veil piercing determines whether the case can be heard by a court or a tribunal outside the host State's legal system and whether it can proceed with the parent company acting as a party to the dispute instead of its subsidiary. While the defendants and claimants in these two types of claim are different, and under IIL it is the State that assumes the obligations under the treaty, in essence, IIL treaties are entered into by States and create enforceable rights for private parties. The framework we propose here envisages a similar arrangement, under which States would sign up to treaty commitments to create rights enforceable by BHR claimants before domestic courts of the home State. ${ }^{77}$ We argue here that policymakers should not shy away from introducing a principled exception to the corporate veil principle to fulfil their duty to protect human rights, even if this means extending liabilities of companies.

The underlying reason behind IIL taking a more lenient approach to corporate veil is because of its having a different objective: extending rights for claimant companies rather than liabilities for defendant companies with a view to encouraging economic activity and risk taking. There appears to be a heightened desire by policymakers to protect economic activity compared to the desire to protect human rights. There is openness to disregarding corporate veil to protect market interests, but extreme caution when it comes to the protection of human rights. This is paradoxically exemplified by looking at how the goals of IIL exceptions on corporate veil and the company law rules on corporate veil overlap, as they both intend to increase economic activity by facilitating risk taking by investors. ${ }^{78}$ There is an eagerness to introduce rules and exceptions necessary to protect investment whilst placing lesser importance on improving human rights protection against business abuses. We argue that the protection of human rights is a

77 See Section VI(C).

${ }^{78}$ In the company law context for corporate veil rules, this is done by primarily shielding investors from the risk of certain damages claims; and in the investment context by protecting investors from certain host State risks. 
policy goal at least as worthy as the promotion of economic activity meaning that, on occasion, the latter should be subjugated to the former.

\section{CHEVRON IN ECUADOR: THE DOUBLE STANDARD COMES TO LIGHT}

The inconsistency outlined above is clearly illustrated in the legal saga involving Chevron's activities (formerly Texaco) ${ }^{79}$ in Ecuador. The main actors of this legal saga are Chevron, Ecuador and the residents in Ecuador's Oriente region. Accounts of Chevron's 'lawfare' in Ecuador have been provided in numerous publications, ${ }^{80}$ and will not be repeated here in detail. For the purposes of this article, we will group the claims into two categories. The first group involves those brought by the residents against Chevron (beginning in the US, continuing in the courts of Ecuador, and now seeking enforcement around the world, including in Canada, ${ }^{81}$ Argentina $^{82}$ and Brazil $^{83}$ ) seeking damages for personal injuries suffered as a result of Texaco's operations in the region. ${ }^{84}$ These consist of infringements of the right to health, right to a healthy environment, right to water, right to food and indigenous rights such as land rights, cultural rights and consultation rights. ${ }^{85}$ The second group consists of the investment treaty claim that was brought before an arbitral tribunal by Chevron against Ecuador under the US-Ecuador BIT seeking compensation for the latter's violation of provisions of the BIT arising from, inter alia, denial of justice in the Lago Agrio $^{86}$ litigation.

79 Chevron and Texaco joined forces in 2001 through a merger. It was Texaco that operated in Ecuador through its subsidiary TexPet until 1992; see the announcement on the completion of the merger <www.chevron.com/stories/chevrontexaco-corporation-announces-completion-ofmerger>.

80 See for instance, S Joseph, 'Protracted Lawfare: The Tale of Chevron Texaco in the Amazon' (2012) 3(1) JHRE 70; J Kimerling, 'Indigenous Peoples and the Oil Frontier in Amazonia: The Case of Ecuador Chevron Texaco, and Aguinda v. Texaco' (2006) 38 NYUJIntlL\&Pol 413; S Patel, 'Delayed Justice: A Case Study of Texaco and the Republic of Ecuador's Operations, Harms and Possible Redress in the Ecuadorian Amazon' (2012) 22 TulaneEnvtlLJ 71; C Giorgetti, 'Mass Tort Claims in International Investment Proceedings: What Are the Lessons from the Ecuador-Chevron Dispute?' (2013) 34 UPaJIntlL 787

${ }^{81}$ Yaiguaje v Chevron Corp, 2013 ONCA 758; Chevron Corp v Yaiguaje, 2015 SCC 42, [2015] 3 SCR.

82 E Garcia and A Valencia, 'Ecuador Plaintiffs to File Lawsuit against Chevron in Argentina' Reuters (Quito, 31 October 2012) <http://www.reuters.com/article/us-ecuador-chevronidUSBRE89U18D20121031>.

${ }^{83}$ E Garcia, 'Ecuador Plaintiffs Target Chevron's Assets in Brazil' Reuters (Quito, 28 June 2012) <http://in.reuters.com/article/ecuador-chevron-idINL2E8HRJX920120628>.

${ }^{84}$ Texaco operated in the region as part of a consortium in which it held a 37.5 per cent stake for the last two decades of its activity in the area. It was the operator of the consortium. See Kimerling (n 80) $420 \mathrm{fn} 17$.

85 Jochnick and Rabaeus (n 14) 433.

86 Maria Aguinda et. al. $v$ Chevron Corporation Lawsuit No 2003-0002, Sucumbíos Provincial Court of Justice; judgment text available at <https:/www.earthrights.org/sites/default/files/ documents/Lago-Agrio-judgment_0.pdf>. 
The first group of actions brought against Chevron for environmental and health damage by the Ecuadorian victims include the initial Aguinda $^{87}$ litigation in the US, followed by the Lago Agrio litigation in Ecuador, and the Yaiguaje ${ }^{88}$ enforcement action in Canada. In each of these proceedings, Chevron has argued that it is a separate entity from its subsidiary TexPet, whose activities allegedly caused the harm, and TexPet's former parent Texaco Inc., and thus cannot be held liable for the harms in question. The initial lawsuit was filed in 1993 in the US. ${ }^{89}$ The plaintiffs argued that the true site of the alleged environmental torts was the US, as the relevant policy decisions had been made at Texaco's US headquarters. The District Court dismissed the case on forum non conveniens grounds, finding that 'a meaningful nexus between the United States and the decisions and practices' which formed the subject of the case was missing. ${ }^{90}$ In Jota $v$ Texaco, ${ }^{91}$ the appeal before the Second Circuit, Texaco elaborated its motion to dismiss the action on forum non conveniens grounds with reference, inter alia, to the legal separation between itself and TexPet. ${ }^{92}$ Similarly in Aguinda $v$ Texaco $^{93}$ the District Court dismissed the claim on forum non conveniens grounds. It held, inter alia, that 'only conduct arguably involving sued oil company was participation by fourth tier subsidiary, not joined as party, in consortium causing damages, with most of subsidiary's activities occurring in Ecuador'. The court found no direct involvement of Texaco parent in the operations of the subsidiary in Ecuador which would warrant disregarding the separate personality between the entities and proceeding to the merits of the claim against Texaco. The District Court conditioned the dismissal on Texaco consenting to submit to personal jurisdiction in Ecuador and to waive the relevant statute of limitations. ${ }^{94}$

Following the dismissal in the US, the Lago Agrio action was brought in Ecuador in 2003 against Chevron and TexPet. ${ }^{95}$ In this litigation, Chevron

87 Aguinda v Texaco 142 F. Supp. 2d 534 (SDNY 2001).

88 Yaiguaje v Chevron Corp, 2013 ONCA 758; Chevron Corp v Yaiguaje, 2015 SCC 42, [2015] 3 S.C.R.

${ }_{89}$ Aguinda v Texaco 142 F. Supp. 2d 534 (SDNY 2001) (Among the reasons for filing the claim in the US, the claimants argued (to fight off the FNC claim) that class actions were not available in Ecuador, that there were procedural deficiencies, there was a need for protracted administrative proceedings prior to the suit, discovery restrictions, cross-examination restrictions and the tendency to have court appointed experts. They also claimed that Ecuador had no comparable procedure to grant plaintiffs the equitable remedy they are principally seeking.)

90 Aguinda v Texaco 142 F. Supp. 2d 534 (SDNY 2001) 13 ('The record before the Court also clearly establishes that all of the Consortium's key activities, including decisions and practices here at issue, were managed, directed, and conducted by Consortium employees in Ecuador. By contrast, no one from Texaco or, indeed, anyone else operating in the United States, made any material decisions as to the consortium's activities and practices that are at issue here.')

91 Jota $v$ Texaco Inc 157 F.3d 153 (2d Cir., 10/05/1998).

92 ibid. ('Texaco had participated in oil drilling in Ecuador exclusively through its fourth-level subsidiary, Texaco Petroleum Company (“TexPet”).')

${ }_{93}$ Aguinda v Texaco 142 F. Supp. 2d 534 (SDNY 2001).

94 Aguinda v Texaco 142 F. Supp. 2d 534 (SDNY 2001).

95 Chevron Corporation acquired Texaco in 2001. 
raised two objections to the Ecuadorian court's jurisdiction that relate to the corporate veil. ${ }^{96}$ First, it claimed that it was not a legitimate defendant as it was not the successor of Texaco Inc., therefore, it could not succeed to Texaco's liabilities, including the latter's obligation to submit to the jurisdiction of the Ecuadoran courts as per the Aguinda judgment. ${ }^{97}$ Second, even if it was treated as the successor of Texaco Inc., it was a separate entity from TexPet, thus could not be held liable for the alleged harm caused by its subsidiary. Both objections were dismissed by the court, a rare occasion.

The second objection on separate personality is useful in illustrating the inconsistency discussed in this paper. Here, Chevron argued that it has never had operations in Ecuador, and TexPet was a separate entity whose liabilities could not be attributed to it. The court stated in respect of this defence that it would need to evaluate whether grounds for lifting the corporate veil existed in order to hold Texaco (and its successor Chevron) liable. At the outset of its assessment, the court emphasized that veil piercing was limited to exceptional situations, such as undercapitalization of the subsidiary to the detriment of third parties and excessive control and involvement over the subsidiary's business that makes the latter the alter ego of the parent. The court held that TexPet could not be considered a distinct legal entity from Texaco (Chevron) as all TexPet's business, financial and technical decisions were made by Texaco. It sought authorization from the parent for the simplest day-to-day running of the company. Furthermore, TexPet was left undercapitalized by Texaco and was unable to meet its obligations. For these reasons, the court sanctioned the piercing of the layers of veil between Chevron and TexPet, as not doing so would cause a manifest injustice. The outcome of the court's interpretation of the traditional veil piercing doctrine here in relation to the Texaco-TexPet-Chevron constellation is an exceptional one.

The Lago Agrio plaintiffs obtained a judgment against Chevron from Ecuadoran courts in the amount of $\$ 9.5$ billion in 2011 , which they have not yet been able to enforce. The issue of corporate veil was resurrected once more during the Yaiguaje enforcement action. Here, the plaintiffs target Chevron and its wholly-owned 7 th tier Canadian subsidiary. In its statement of defence to the enforcement action, ${ }^{98}$ Chevron stated that 'a subsidiary of Chevron Corp. merged with Texaco and thus, Texaco and TexPet became indirect subsidiaries of Chevron Corp. Following this transaction, Chevron

96 Maria Aguinda et. al. v Chevron Corporation (n.86); Joseph (n 80) 75.

97 This was based on the fact that Chevron acquired Texaco via a reverse triangular merger, whereby Chevron created a subsidiary called Keepap Inc. which merged with Texaco, and the latter continues to exist as a separate legal entity and a subsidiary of Chevron. The Court rejected the claim and held that the real effect of the transaction behind the formal appearances was a de facto merger between Chevron and Texaco; see Maria Aguinda et. al. v Chevron Corporation (n 86).

98 Statement of Defence of Chevron Corporation to the Ontario Superior Court of Justice, dated 2 October 2015, para $26<$ https://www.italaw.com/sites/default/files/case-documents/italaw4407. pdf>. 
Corp., Texaco and TexPet continued as separate legal entities and they have remained so ever since.' Chevron argued there that it has never operated or owned assets in Ecuador, has not participated in any way in the Consortium, Texaco and TexPet are legally separate entities from Chevron, and there has never been any valid reason to disregard the separate personalities of these entities. ${ }^{99}$ The plaintiffs sought to pierce Chevron Canada's corporate veil to satisfy a judgment rendered against Chevron. ${ }^{100}$ The first instance court dismissed the plaintiff's request for piercing the veil in the absence of complete domination of the subsidiary coupled with 'wrongdoing akin to fraud'. ${ }^{101}$

Chevron's arguments run in the opposite direction in the IIL claim it brought against Ecuador. There, Chevron claims, inter alia, that Ecuador's conduct regarding the Lago Agrio case violated the US-Ecuador bilateral investment treaty's denial of justice provisions, ${ }^{102}$ as well as its protections on fair and equitable treatment. ${ }^{103}$ In this claim, Chevron invoked the treaty against Ecuador relying on its historical investment in Ecuador via Texaco and TexPet. As the parent company, Chevron is seeking the protection of the treaty which explicitly allows parent companies to advance claims, as protected investors, for the alleged harms done by the host State to their subsidiary. ${ }^{104}$ According to Chevron, its investment in Ecuador that deserves the protection of the BIT consists of 'TexPet's underlying oil operations in Ecuador', and '[TexPet's] rights under the Settlement Agreements' signed by and between Ecuador and TexPet, releasing the latter from liability. ${ }^{105}$ The tribunal held that 'as TexPet's parent company, Chevron is a covered investor under [the BIT] because it indirectly owns or controls an "investment" in Ecuador'. ${ }^{106}$ This is a prime example of treaty-based reverse veil-piercing.

In the IIL proceedings, Chevron argued that it met the threshold of involvement with its subsidiary's business in Ecuador, whilst in the domestic claims by the BHR victims; it argued that it did not meet that threshold of

\footnotetext{
99 ibid, para 30.

100 This is a case of reverse veil piercing, where the assets of the subsidiary are pursued for liability of the parent. $\quad 101$ Yaiguaje v Chevron Corporation 2017 ONSC 135, 20/01/2017.

102 Chevron argued that '[Ecuador] has pursued a coordinated strategy with the Lago Agrio plaintiffs that involves [Ecuador]'s various state organs ... that [Ecuador]'s judicial branch has conducted the Lago Agrio litigation in total disregard of Ecuadorian law, international standards of fairness and Chevron's basic rights as to due process and natural justice, in coordination between [Ecuador] and the Lago Agrio plaintiffs.' See Chevron Corporation and Texaco Petroleum Company $v$ The Republic of Ecuador, PCA Case No 2009-23 Third Interim Award on Jurisdiction and Admissibility (27 February 2012) para 3.39.

103 In this respect, Chevron claims that Ecuador violated the a series of agreements signed by Ecuador and TexPet in 1995, 1996 and 1998 that aimed to release TexPet from liability for consequences of the environmental damage caused by the operations of TexPet in the Oriente Region; see ibid para 1.28. $\quad 104$ ibid para 3.102 and 3.235. 105 ibid para 3.61.

106 ibid para 4.24.
} 
involvement with its subsidiary's business in Ecuador. ${ }^{107}$ This was possible because, as discussed above, the level of involvement sufficient in IIL to disregard corporate veil is much less than that required under company law rules in most jurisdictions. Even though both cases involve the same constellation of facts regarding corporate structure, in the first group of cases mentioned above, Chevron, in an attempt to distance itself from TexPet, repeatedly invoked the corporate veil, while in the IIL claim it was able to successfully argue for disregarding the corporate veil in order to benefit from an investment treaty protection. The latter was readily accepted by the investment tribunal, as the US-Ecuador BIT explicitly allows reverse veil piercing. The former had to be argued up and down the legal process over the past 23 years in various jurisdictions including the US, Canada, and Ecuador.

VI. ADOPTING THE TREATY-BASED VEIL PIERCING AND THE 'CONTROL' RULE IN THE BHR CONTEXT

The State duty to protect under international human rights law comprises a duty to ensure that victims of human rights abuses committed by third parties have access to effective domestic remedies. ${ }^{108}$ This core principle is reflected in the BHR context in the third pillar of the UNGPs, requiring both States and businesses to provide remedies when abuses occur. Particularly relevant here is the UNGP 26, which requires States to remove obstacles to access to judicial remedies, by reducing 'legal, practical and other relevant barriers that could lead to a denial of access to remedy'. The commentary to UNGP 26 lists, as examples of legal barriers, the ability of businesses to avoid liability using strategic corporate structuring and the inability of victims to access home State courts even when they face a denial of justice in the host State. The framework advanced in this article aims to allow BHR claimants to pursue the parent company in its home jurisdiction for harm caused by the latter's subsidiary.

\section{A. 'Veil Piercing'}

The model we propose here allows disregarding the veil between the host State entity and the parent company, as well as the veils of the layers of subsidiaries between the two entities where necessary. This is made possible by the adoption of a 'control' test, primarily borrowed from the IIL model, to identify the proper

\footnotetext{
107 Chevron claims in its pleadings to the tribunal that it is Ecuador that is trying to 'have it both ways' by holding Chevron liable in the Lago Agrio litigation while also arguing in the IIL claim that Chevron is not entitled to bring the arbitration as it has no investment in Ecuador; see ibid para 4.25.

108 See for instance, art 2.3 of International Covenant on Civil and Political Rights and UNCHR, 'General Comment No.31, Nature of the General Obligation Imposed on States Parties to the Covenant', (26 May 2004) CCPR/C/21/Rev.1/Add.13, para 8. See also O De Schutter, 'Towards a New Treaty on Business and Human Rights' (2016) 1 BHRJ 41, 44.
} 
defendant/s in the upstream ownership structure of the subsidiary. Veil piercing under this model aims to overcome the obstacles created by separate personality and limited liability in three stages of access to a judicial remedy by BHR claimants: jurisdiction, substance and enforcement. At each of these stages, the question of whether the veil can be pierced will have to be answered separately.

At the jurisdictional stage, veil piercing would operate to allow courts in the home State of the entity controlling ${ }^{109}$ the subsidiary to assume jurisdiction over the claim, despite the overseas locus of the harm and distinct identity of the overseas subsidiary. This way, the BHR claimants would overcome the potential obstacles, such as the forum non conveniens principle or the lack of sufficient proximity between the forum and the claim, when pursuing a parent company and its subsidiary in home State courts. Overcoming this obstacle would mean that the claim will proceed before the home States' courts to the merits stage, rather than being dismissed on the grounds that the host State is a more appropriate forum despite the serious challenges to obtaining a remedy there. This could, for instance, have allowed the Aguinda litigation to proceed in the US against Texaco, as long as Texaco fulfilled the definition of a 'controlling entity' within the meaning of this proposed framework.

The ability to pierce the veil to enable home State courts to exercise jurisdiction does not automatically establish the liability of the parent company. The second stage of the enquiry will be whether the parent can be held liable for its subsidiary's actions or omissions. There will be two elements to this. One side of the liability coin is whether the veil can be pierced to overcome the limited liability principle. If this can be answered in the positive, the plaintiffs would still need to establish that their rights under the applicable domestic law or treaty were breached by the subsidiary or the parent. So at this juncture, an ability to pierce the veil alone will not automatically establish parent liability. It needs to be accompanied by substantive protections concerning the rights of the BHR claimants and a standard of care expected from the parent or the subsidiary established in domestic law or in the applicable treaty. At the merits stage, veil piercing would assist in attributing liability to the controlling entity for harm ostensibly caused by the host State subsidiary, regardless of the legal distance created by layers of intermediary companies. This would allow for (1) the pursuit of the parent company before host State courts, where the local subsidiary is defunct or underfunded; and, (2) pursuit of the parent company before home State courts. In the Aguinda litigation, our proposal would have allowed the US court to consider whether to hold Texaco liable for the harm allegedly caused by its subsidiary, as long as Texaco fulfilled the definition of a 'controlling entity' within the meaning of this proposed framework. Again, the BHR claimants would have thus sidestepped the domestic law

109 The meaning of control for this proposal is explained in Section VI.B. 
requirements for piercing the corporate veil, which are extremely difficult to satisfy, ${ }^{110}$ to hold shareholders of a company liable for harm caused by the latter's activities.

Finally, at the enforcement stage, the model will allow judgments made against the subsidiary to be enforced against the parent company where the judgment debtor subsidiary is defunct or does not have enough assets to meet its debts. This will allow, for instance, judgments rendered in host States against such defunct or impecunious subsidiaries to be enforced against the assets of the controlling entity, as long as those assets are located in a State signatory to the treaty introducing our model. ${ }^{111}$ The proposed rules on enforcement would, however, not allow enforcement against sister corporations (so called 'horizontal veil piercing' ${ }^{112}$ ) within the same group that do not qualify as a 'controlling entity'. Thus, the proposed model would not make a difference for the enforcement of the Lago Agrio judgment, as the latter was made against the Chevron parent in the first place, and as such should be enforceable against the parent's assets, as long as the judgment complies with the rules on recognition and enforcement of foreign judgments in the chosen place of enforcement. ${ }^{113}$ The proposed enforcement rules would make a difference for the victims that are able to obtain award for damages against the subsidiary in the host State for the human rights harm suffered, but who are not able to enforce the judgment against the subsidiary for the reasons explained earlier. ${ }^{114}$

\footnotetext{
110 Particularly, where layers of corporate intermediaries are inserted into the investment structure.

111 This would not interfere with the operation of the existing bilateral or multilateral treaties on enforcement of foreign judgments in civil and commercial matters. Our proposal does not aim to overlap with those treaties but complement them with special rules on enforcement of judgments rendered against a subsidiary against the assets of the parent company located overseas. The recognition and enforcement of the judgment rendered in the host State before home State courts would follow the procedure prescribed in such treaties, or in the lack thereof, the domestic procedural rules on recognition and enforcement of foreign judgments. Our proposal would add to those rules by allowing the enforcement of the judgment otherwise recognized against the assets of the parent company.

112 M Dearborn, 'Enterprise Liability: Reviewing and Revitalizing Liability for Corporate Groups’ (2009) 97(1) CLR 195, 211.

113 Enforcement of the Lago Agrio judgment has so far not been successful. Claimants are avoiding enforcement in the US, where Chevron is headquartered, due to a US court decision declaring the judgment as tainted by corruption; See Chevron Corp. v Donzinger No.14-0826 (2d Cir. 2016); an enforcement action was brought in Canada against the assets of a Canadian subsidiary of Chevron and the shares of Chevron parent in that subsidiary. This action was challenged by Chevron on numerous grounds, including the Canadian court's jurisdiction to enforce the Lago Agrio judgment (this portion of the challenge was dismissed), as well as the challenges on public policy grounds (these are yet to be decided by the Supreme Court) Yaiguaje v Chevron Corp, 2013 ONCA 758; Chevron Corp v Yaiguaje, 2015 SCC 42.

114 In Adams v Cape Industries Plc [1991] 1 All ER 929 the defendant parent company liquidated its US subsidiary and then successfully resisted in England the enforcement of a judgment obtained in the US for health harm caused by asbestos products.
} 


\section{B. 'Control'}

The trickiest part of proposing a model for a treaty-based veil piercing is to develop a satisfactory and sufficiently encompassing definition of 'control' that will determine the target entity, ie the defendant, behind the corporate veil. Even a detailed prescription of this concept would have to be applied in individual cases through judicial interpretation, sometimes with potentially unforeseen outcomes. Thus, a meaning of control is presented here with that caveat in mind.

The understanding of 'control' under IIL provides guidance by analogy. Despite the lack of a uniform definition of control adopted in IIL, there is a level consistency in the understanding of 'control' throughout the system owing to its investor-friendly spirit. This spirit is reflected in how generously the concept of 'control' has been defined in treaties and interpreted in awards, aiming to push for greater protection of investors via a broader application of treaties and exercise of jurisdiction by arbitral tribunals.

IIL accepts that control of the local subsidiary could be exercised via ownership of shares, voting rights or management rights, or a combination thereof. IIL definitions of control recognize that control can be exercised by direct or indirect holders of shares, voting rights or management rights in a company, thus catering for there being layers of intermediaries between the host State subsidiary and its controlling parent. Thus, IIL adopts a legal 'control' approach and not a day-to-day control approach. Control in the IIL context is not used as a reference to active involvement in the business activities and decisions of the subsidiary. It is also not linked to whether the controlling entity was under a due diligence obligation for the behaviour of its subsidiaries. Nor does it question whether the parent had assumed responsibility under a standard of duty of care vis-à-vis the persons harmed by the activities of the subsidiary. It is a reference to the interest of the foreign party who is 'behind' or has 'made' the investment.

By adopting a liberal 'control' rule, IIL aims to cater for the realities of making a foreign investment, when investments are carried out via a local subsidiary. ${ }^{115}$ If treaty-based veil piercing was not allowed under IIL, foreign investors operating via local subsidiaries would be significantly limited in their ability to invoke IIL protections. IIL does not require investors to show that they had any active involvement in the policies or the activities of the subsidiary to establish control. Instead, it simply recognizes the need for protection due to the economic interest of the parent in the subsidiary. This economic interest of the parent in the subsidiary is also a reality in the BHR context. We propose that a new treaty on BHR should take this economic interest into account in regulating access to remedy by allowing claims to be brought against direct or indirect controllers of host State subsidiaries. Sometimes the ability to reach the

115 CH Schreuer et al. (n 66) 296. 
deeper pockets of the parent company will make access to remedy possible for BHR claimants. Beyond the remedy provided to individual victims, exposing the parent to liability can have a preventative effect by potentially pushing the parent to ensure better institutional behaviour throughout the group. Even if potential liability deters some businesses from making otherwise economically and socially beneficial investments, that is a risk worth taking to improve respect for human rights.

The IIL model makes parent companies more accessible to claimants by eliminating the necessity to show a certain level of parent involvement in the harmful activity of the subsidiary. It is often extremely difficult for business and human rights claimants to prove the required levels of involvement, as they often have no access to internal company documents that might prove such involvement. To overcome these challenges, we propose to transpose the liberal understanding of 'control' observed in IIL into our model, based on direct or indirect ownership rights and not on the level of active involvement in subsidiary policies. The treaty could also stipulate the threshold of control proposed below as a trigger for the substantive obligations of a parent company, such as the duty of care or human rights due diligence obligations, vis-à-vis the BHR claimants.

IIL does not provide clarity as to the extent of ownership rights that would amount to 'control' within the meaning of IIL. We consulted several proposals from leading scholars writing on the issue of the corporate veil in the context of BHR, which range from 20 per cent to 51 per cent shareholding when defining control. ${ }^{116}$ The lowest threshold was proposed by Simons and Macklin in their proposal for a negligence-based home State civil liability regime. ${ }^{117}$ Among the indicators of control proposed in their book is direct or indirect ownership of ' 20 per cent of the voting interests in an affiliate or other business entity'. ${ }^{118}$ They find support for this threshold in securities law by reference to the meaning of control under the Ontario Securities Act which 'creates a rebuttable presumption that someone can materially control an entity through a 20 per cent interest'. ${ }^{119}$

116 Simons and Macklin (n 75); De Schutter (n 108), Skinner (n 11); 'Control' is also advanced as one of the determinants of 'connected claims' for purposes of jurisdiction of a domestic court under the Sofia Guidelines for the Best Practices for International Civil Litigation for Human Rights Violations. In art 2.2, the Guidelines treat claims closely connected where defendants are related either because they form part of the same corporate group or one defendant controls the other; see The ILA Sofia Conference, International Civil Litigation for Human Rights Violations Final Report, 31 (The Report does not describe in detail what control means in this context, other than saying that it is 'normally defined on the basis of stock ownership', but it could be extended to contractual relationships where for instance there is a relationship of dependency between a supplier and a purchaser.).

117 Simons and Macklin (n 75) 286.

118 Simons and Macklin (n 75) 356 don't limit the indicators of control to share ownership, and also refer to the ability of one company to ordinarily direct or instruct the conduct of another company, power to elect at least 30 per cent of the $\mathrm{BoD}$ of an affiliate, power to direct the management and policies of the other entity, or otherwise have the ability to materially influence the behaviour of the other entity.

119 Simons and Macklin (n 75) 356, n 201. 
Skinner proposes a statute-based model that will allow courts to:

disregard limited liability of parent corporations for claims of customary international human rights violations and serious environmental torts where a parent corporation takes a majority interest or creates a subsidiary as part of a unified economic enterprise .... ${ }^{120}$

The report does not elaborate on the meaning of 'majority interest' or 'creation of a subsidiary as part of a unified economic enterprise'. Majority interest is usually understood as holding at least 50 per cent interest in the company. In terms of the material scope of the proposal, Skinner does not elaborate on what would constitute customary international human rights violations and serious environmental torts, but states that she opted to limit the claims, as it would be more difficult to persuade policymakers to adopt this type of parental liability for general torts.

In his article in support of the proposed treaty on business and human rights De Schutter recommends the adoption of an extraterritorial obligation on home States to impose on parent companies located in their jurisdiction a due diligence obligation, defined by statute, to effectively monitor the behaviour of the subsidiaries which it 'controls.' He then defines control with reference to stock ownership of $50 \%$ and above, and this way removes the need to assess, on a case by case basis, the involvement of the parent in the policies and activities of the subsidiary. ${ }^{121}$

We find additional inspiration in each of these proposals in unpacking the elements of our model, while our primary inspiration remains IIL. Common to all the above proposals is the aim to incorporate an exception to the traditional corporate veil doctrine into a legally binding instrument. The instrument of choice in these proposals is statute, while in ours it is a treaty. The reason why we opted for the treaty is that, if successful, it would have the effect of creating a level playing field. While Skinner and De Schutter refer only to 'majority interest' as determinant of control, we propose a model which is more flexible and accommodating to variants of group governance models, similar to Simons and Macklin.

In more precisely defining the meaning of control we found most useful the legislative guidance in the EU Accounting Directive ${ }^{122}$ describing 'control' in corporate groups for purposes of consolidated reporting. Instead of prescribing a single indicator or percentage of ownership for control, it provides a definition that accommodates the potential variations in the governance of a corporate group. Its rules are realistic and sufficiently detailed. Furthermore, certain large companies in the EU are now required to include in their consolidated

Directive 2013/34/EU of the European Parliament and of the Council of 26 June 2013 on the annual financial statements, consolidated financial statements and related reports of certain types of undertakings [2013] OJ L182/19. 
annual report information on human rights, ${ }^{123}$ and there might be more jurisdictions adopting this type of human rights reporting. It would be useful to align the meaning of control for purposes of civil claims with that of the reporting requirement. Pursuant to Article 22 (1) of the Directive a parent company $^{124}$ controls a subsidiary ${ }^{125}$ if it:

(a) has a majority of the shareholders' or members' voting rights in another undertaking (a subsidiary undertaking);

(b) has the right to appoint or remove a majority of the members of the administrative, management or supervisory body of another undertaking (a subsidiary undertaking) and is at the same time a shareholder in or member of that undertaking;

(c) has the right to exercise a dominant influence over an undertaking (a subsidiary undertaking) of which it is a shareholder or member, pursuant to a contract entered into with that undertaking or to a provision in its memorandum or articles of association, where the law governing that subsidiary undertaking permits its being subject to such contracts or provisions. ...

(d) is a shareholder in or member of an undertaking, and:

(i) a majority of the members of the administrative, management or supervisory bodies of that undertaking (a subsidiary undertaking) who have held office during the financial year, during the preceding financial year and up to the time when the consolidated financial statements are drawn up, have been appointed solely as a result of the exercise of its voting rights; or

(ii) controls alone, pursuant to an agreement with other shareholders in or members of that undertaking (a subsidiary undertaking), a majority of shareholders' or members' voting rights in that undertaking... .

We propose the adoption of the same approach. ${ }^{126}$ The existence of control for purposes of treaty-based veil piercing will be satisfied where an investor, directly or indirectly, holds a majority of the voting rights in the local subsidiary; or the amount of shares or other rights held give it the right to appoint or remove a majority of the subsidiary's management board members; or contractual arrangements between shareholders or provisions of

123 Directive 2014/95/EU of the European Parliament and of the Council of 22 October 2014 amending Directive 2013/34/EU as regards disclosure of non-financial and diversity information by certain large undertakings and groups [2014] OJ L330/1.

124 Art 2(9) defines parent company as 'an undertaking which controls one or more subsidiary undertakings'.

125 Art 2(10) defines a subsidiary as 'an undertaking controlled by a parent undertaking, including any subsidiary undertaking of an ultimate parent undertaking'.

126 A similar definition is also found in section 1159 of the Companies Act 2006. 
the subsidiary's constitution give it the right to exercise influence that would be otherwise exercised by a majority shareholder.

A final point on control involves investments carried out in the host State through joint venture structures with other partners. These joint venture investments might operate through a separate legal entity incorporated in the host State or in another jurisdiction. ${ }^{127}$ In other cases, the joint venture might operate without a separate entity, only via contractual arrangements. If it is possible to identify a joint venture partner that satisfies the description of 'control' provided in the preceding paragraph, the liability would lie with that entity. If no single entity participating in the joint venture fulfils the above definition, who should bear the responsibility? Drawing an analogy from IIL cases where non-majority partners in investments brought claims against host States for their share of loss, ${ }^{128}$ it should be possible for BHR victims to pursue each joint venture partner, including the operator of the joint venture, and their parent companies, under a joint and several liability framework.

\section{C. 'Treaty-Based'}

We propose this model to be incorporated into a draft convention with the effect of creating directly enforceable rights by covered BHR claimants capable of enforcement against parent companies who violated their human rights. In this sense, it is analogous to IIL protections found in treaties signed by States, enforceable by non-State actors, i.e., investors, or to the regional human rights treaties that create rights enforceable by individuals before the regional human rights courts. One of the reasons behind the success of the international framework for the protection of foreign investment is that it is supported by an extensive network of treaties. Unlike BHR claimants, investors do not have to rely merely on soft law principles or domestic law standards to safeguard their rights, but they receive the backing of legally binding international commitments.

A treaty-based protection framework for human rights harm caused by businesses would help ensure that human rights obligations of businesses have 'at least equal status' as the rights guaranteed to them under IIL and

\footnotetext{
127 The latter was the case for Talisman's investment in Sudan. P Simons and A Macklin (n.75) 28 “On 17 August 1998 Talisman agreed to buy Arakis Energy's 25 per cent share in the GNPOC joint venture for approximately US $\$ 277$ million. GNPOC was registered as a corporation in Mauritius. Talisman operated in Sudan through its Dutch-registered subsidiary Talisman Greater Nile BV (TGNBV)." 40 per cent of the JV was held by the China National Petroleum Corporation and 30 per cent by the national oil company of Malaysia.

${ }^{128}$ Many cases filed against Argentina in the aftermath of the 2001 financial crisis were based on 'shares' as investment; See for instance, Enron Corporation and Ponderosa Assets, L. P. v. Argentine Republic (Decision on Jurisdiction) (ICSID Arbitral Tribunal Case No.ARB01/3, 14 January 2004); AES Corporation v The Argentine Republic (Decision on Jurisdiction) (ICSID Arbitral Tribunal Case No. ARB/02/17, 26 April 2005); Teinver S.A., Transportes de Cercanias S.A. and Autobuses Urbanos del Sur S.A. v. The Argentine Republic (Decision on Jurisdiction) (ICSID Arbitral Tribunal Case No.ARB/09/1, 21 December 2012).
} 
international trade law. ${ }^{129}$ In the more specific context of access to remedy for BHR claimants, a treaty commitment would procedurally empower the victims by opening new avenues for making 'rights demands' with higher likelihood of success than would be the case in the absence of treaty provisions enhancing access to remedy. ${ }^{130}$ Procedural empowerment of investors via a right to bring direct international law claims against host States is considered IIL's most revolutionary aspect. ${ }^{131}$ Our model proposes a similar kind of procedural empowerment backed by international law for BHR claimants.

In addition to its force, a treaty-based model would allow this framework to be implemented more effectively. Due to the multi-jurisdictional nature of the corporate structures involved, having, for instance, only a group of individual host States incorporating the model into their national law sporadically without home State adherence to the same principles would undermine the functioning of the model. Without an international instrument threading commitments together and matching host State-home State commitments, individual States would be less willing to sign up to a race to the top. ${ }^{132}$

We envisage two possible host instruments for the model proposed here: (1) it could be incorporated into the proposed BHR treaty, or (2) into investment treaties, existing or future. ${ }^{133}$ While a multilateral treaty on BHR would potentially provide a wider coverage of protection, the obvious disadvantage of taking that path is the difficulty of reaching consensus on a global treaty, if consensus is reached at all. ${ }^{134}$ Even if a consensus is seemingly reached, if only

129 D Bilchitz, The Moral and Legal Necessity for a Business and Human Rights Treaty $<\mathrm{https}: / /$ business-humanrights.org/sites/default/files/documents/The $\% 20 \mathrm{Moral} \% 20$ and $\% 20 \mathrm{Legal} \%$ 20 Necessity $\% 20$ for $\% 20 \mathrm{a} \% 20$ Business $\% 20$ and $\% 20$ Human $\% 20$ Rights $\% 20$ Treaty $\% 20$ February $\%$ 202015\%20FINAL\%20FINAL.pdf> at 9. D Bilchitz, 'The Necessity for a Business and Human Rights Treaty' (2016) 1 BHRJ 203, 215.

${ }_{130}$ BA Simmons, Mobilizing for Human Rights: International Law in Domestic Politics (Cambridge University Press 2009) 125 (argues that 'treaties are causally meaningful to the extent that they empower individuals, groups, or parts of the State with different rights preferences that were not empowered to the same extent in the absence of the treaties').

131 BA Simmons, 'Bargaining over BITS, Arbitrating Awards: The Regime for Protection and Promotion of International Investment' (2014) 66(1) World Politics 12, 17.

132 Bilchitz, 'The Necessity for a Business and Human Rights Treaty' (n 129) 218-19.

133 A multilateral convention that aims to establish universal jurisdiction in signatory States over civil suits for remedying human rights violations was previously proposed; See B Stephens, 'Translating Filartiga: A Comparative and International Law Analysis of Domestic Remedies for International Human Rights Violations' (2002) 27 YaleJIntlL 1. Similarly incorporation of a civil liability framework, offering three options to overcome the separate personality challenge (enterprise liability, liability insurance or posting a bond as security), in investment treaties was proposed by JA VanDuzer et al., 'Integrating Sustainable Development into International Investment Agreements: A Guide for Developing Countries' (2012) Prepared for the Commonwealth Secretariat, <www.iisd.org/pdf/2012/6th_annual_forum_commonwealth_guide. pdf $>$; While our model finds inspiration and support in those proposals, (1) it does not advocate universal jurisdiction, (2) it takes IIL rules on treaty-based veil piercing as a model and not the enterprise liability model (3) provides greater detail regarding the elements of the treaty-based veil piercing exercise in the context of B\&HR litigation.

134 D Cassel and A Ramasastry, 'White Paper: Options for a Treaty on Business and Human Rights' (2015) 6 Notre Dame Journal of International and Comparative Law 1 (they identify the 
a small number of States give ratification, the proposed model is unlikely to fulfil its goal. The investment treaty route appears more achievable in that sense, as it requires the consensus of two States, or at most a limited number of States within a particular region. It also secures host and home State commitments. There are recent examples of investment treaties from the global south that move towards recognizing the rights of host communities to seek remedies in the investor's home State. ${ }^{135}$ The disadvantage of the investment treaty route is its ad hoc non-centralized nature. This feature actually motivated more States to conclude BITs due to host States' desire to attract capital and home States' desire to enter into new markets under favourable terms. ${ }^{136}$ In competing for markets and capital, treaty commitments protecting investment were perceived beneficial for all parties involved. ${ }^{137}$ Lack of comparable powerful incentives in the BHR context to convince States to adopt the model proposed here is unfortunately a limitation of our proposal. Opening up a new avenue of liability for businesses, as proposed in this article, is unlikely to attract a race between States to sign up. States' perception that regulation of business would adversely affect flows of investment and opposition of powerful economic actors with strong influence, via lobbying, on the investment treaty negotiation process ${ }^{138}$ are likely to discourage States from committing, unless they can be convinced they will not be at a competitive disadvantage by doing so. ${ }^{139}$ In this respect, a multilateral BHR treaty could secure a level playing field in this area. However, the investment treaty regime is going through a reform process as States from all levels of development negotiate new generation investment treaties, and the inclusion of investor obligations and rights of third parties in these treaties is becoming increasingly salient. ${ }^{140} \mathrm{~A}$ reasonable middle path might be the adoption of the model initially in

key options and challenges for a potential treaty on business and human rights); L McConnell, 'Assessing the Feasibility of a Business and Human Rights Treaty' (2017) 66 ICLQ 143 (advances a theoretical model for a treaty that addresses non-State actors directly).

135 See Section 20 of the Morocco-Nigeria BIT.

136 Simmons (n 131) 20-1(causing a sharp increase in the number of BITs in the 1980s and 1990s).

137 Whether BITs have been beneficial to host economies is disputed; see KP Sauvant and LE Sachs The Effect of Treaties on Foreign Direct Investment: Bilateral Investment Treaties, Double Taxation Treaties, and Investment Flows (Oxford University Press 2009); J Tobin and S RoseAckerman 'When BITs Have Some Bite: The Political-Economic Environment for Bilateral Investment Treaties' (2011) 6(1) The Review of International Organizations 1; A Kerner, 'Why Should I Believe You? The Costs and Consequences of Bilateral Investment Treaties' (2009) 53 (1) International Studies Quarterly 73.

138 See for instance, the work of Corporate Europe Observatory on corporate lobbying for TTIP, $<$ https://corporateeurope.org/international-trade/2015/07/ttip-corporate-lobbying-paradise $>$.

139 For a detailed account of the problem of prisoners' dilemma and collective action in the context of international law, see KW Abbott, 'Modern International Relations Theory: A Prospectus for International Lawyers' (1989) 14 YaleJIntlL 335.

${ }_{140}$ See for instance, the EU's investment and trade policy at $<$ http://ec.europa.eu/trade/policy/infocus/new-trade-strategy/>; The Morocco-Nigeria BIT; The Model Text for the Indian Bilateral Investment Treaty, available at $<\mathrm{http}: / /$ dea.gov.in/sites/default/files/ModelBIT_Annex_0.pdf $>$. 
regional investment treaties, such as those that are being pursued by the EU. ${ }^{141}$

\section{D. 'Scope of Application'}

A major question about a treaty on BHR is which human rights it would cover. ${ }^{142}$ It goes beyond the scope of this article to provide an appropriate solution to that question. However, it is necessary to touch on the subject in order to determine the scope of application of the proposed treaty-based veil piercing. The material scope of the proposed framework would depend on the host instrument. If the model is adopted in an investment treaty, the material scope could be limited to civil liability, ie tort or delict, claims against the investor by individuals for violations that amount to harm to human rights recognized in the two Covenants, or it could be limited to the IHRL obligations signed up to by the host State. ${ }^{143}$ If the model is incorporated into a future treaty governing human rights responsibilities of businesses, the material scope of the proposed civil liability framework would be determined by reference to the human rights included within the scope of that treaty. ${ }^{144}$ In both cases, the law governing the substance of the civil claim would be determined with reference to the conflict of law rules of the lex fori.

The personal scope of the framework would also depend on the host instrument. If the model is implanted into a BIT, it would include a second group of beneficiaries to the treaty, ie BHR claimants, in addition to investors. This would render covered investors indirect duty bearers under the treaty in addition to being right holders. It would be enforceable by individuals harmed in the host State to the BIT against 'investors' located in the home State. If it is included in a specialized treaty on BHR, the rights provided would be enforceable against controlling entities located in home States signatory to the treaty for harm caused in both signatory and nonsignatory host States.

Finally, IIL protections are safeguarded via the IIA mechanism outside local courts, and thus they do not require signatory States to incorporate these protections into their national law. The rights envisaged for BHR claimants in our model require enforcement at the local level by national courts in the host and home States. ${ }^{145}$ The proposed treaty-based model would oblige the

141 The EU Commission's DG on Trade has set out its investment and trade policy at <http://ec. europa.eu/trade/policy/in-focus/new-trade-strategy/>.

142 Cassel and Ramasastry (n 134) 38.

143 This could prove problematic if the host State has not ratified major human rights treaties, or if the B\&HR claimants invoke a right contained in a treaty ratified by the host State but not by the home State before the latter's courts.

144 There is yet no consensus on the precise substantive scope of the B\&HR treaty within the intergovernmental working group; see C Lopez and B Shea, 'Negotiating a Treaty on Business and Human Rights: A Review of the First Intergovernmental Session' (2016) 1(1) BHRJ 111, 114.

145 Under our model, victims could sue in home or host State courts, the former more commonly as a result of the access to remedy issues in certain host States, discussed above. 
signatory States to adjust their domestic law to accommodate the claims envisaged. However, depending on the domestic constitutional requirements of the signatory States, the framework might require implementation into national law to take effect. ${ }^{146}$

\section{CONCLUSION}

Laws governing business enterprises and business transactions were designed and have developed, nationally and internationally, to increase, and facilitate economic activity, without necessarily taking into consideration other interests in society. These underlying rationales of laws governing business activity dictate how legal principles are interpreted when there is ambiguity or clash with a non-economic interest. ${ }^{147}$ In parallel to developments in the economic field, human rights law has also developed into significant body of law, with the aim of eliminating abuse of power by States, compelling States to ensure basic rights are guaranteed and holding States accountable nationally and internationally where violations occur.

These two streams of legal principles have, for the most part and for many decades, developed in isolation from each other. ${ }^{148}$ Corporate/commercial lawyers dealt little, if at all, with human rights law, likewise human rights lawyers for the most part have paid little attention to economic actors and laws governing businesses. ${ }^{149}$ This, however, is no longer the case. The increasing interaction between these fields has been recognized in the past few decades and the need to think about human rights obligations of business enterprises has already been advanced and discussed by many, whether through State regulation or by direct attribution of these obligations to companies, the latter less successfully. ${ }^{150}$

Following in this wind of change, we argue that this new thinking calls for redrawing the boundaries of the most basic principles of corporate law, ie separate personality and limited liability, without leaving these basic principles devoid of meaning. Instead of treating the disregarding of the corporate veil as a no-go area that can only be visited in extremely rare occasions allowed by corporate law, policymakers should introduce new and carefully thought out exceptions to these core corporate law principles which aim to safeguard the protection of fundamental rights of the wider society. In this spirit, theories of enterprise liability, direct parent liability, and due

146 See E Denza, 'The Relationship between International and National Law' in MD Evans (ed), International Law (4th edn, Oxford University Press 2014) 412-40.

147 See for a comprehensive analysis of balancing competing interests in the context of foreign investment S Leader, 'Human Rights, Risks and New Strategies for Global Investment' (2006) 9(3) JIEL 657.

148 D Shelton, 'Protecting Human Rights in a Globalized World' (2002) 25(2) BCIntl\&CompLRev 273, 279-80. 149 van Dam (n 20) 225-6.

150 See Shelton (n 148) 273ff; Muchlinski (n 26); V Harper Ho, 'Of Enterprise Principles and Corporate Groups: Does Corporate Law Reach Human Rights?’ (2013) 52 ColumJTransnatlL 113. 
diligence standard have been proposed by leading scholars as models to overcome the accountability gap by separate personality. Policymakers and courts have been slow in embracing these proposals so far. ${ }^{151}$

We propose to import the IIL rules on treaty-based veil piercing that operate to protect investors into a framework for protection of individuals against human rights harm inflicted by the same investors. Like previous proposals, ours aims to open up the possibility of assessing which entity within a corporate group should bear responsibility by allowing courts to look behind the formality of corporate legal structure in appropriate cases and to apportion blame more fairly. It aims to do so by putting human rights claimants on a similar footing with investors in IIL claims. A treaty commitment to remove the corporate veil obstacle to access to remedy would support the ongoing efforts at national and the international levels to guarantee corporate respect for human rights.

151 The first example of a mandatory human rights due diligence requirement for certain very large businesses is established by the new French legislation on Duty of Vigilance for parent companies LOI nº 2017-399 du 27 mars 2017 Art. L. 225-102-4.-I. 